\title{
IMAGENS QUE (NOS) DEVORAM: \\ REFLEXÕES SOBRE TIGRES, JORNALISMO CIDADÃO E COBERTURAS JORNALÍSTICAS
}

\author{
Images that devour us: \\ reflections on tigers, citizen journalism and news coverage
}

\begin{abstract}
Imágenes que nos devoran:
reflexiones sobre tigres, periodismo ciudadano y la cobertura de noticias
\end{abstract}

Monica Martinez

Professora da Uniso (Sorocaba - SP) martinez.monica@uol.com.br

\begin{abstract}
Resumo: Esse estudo propõe reflexões acerca da imagem e dos relatos jornalísticos a partir da comparação do conteúdo de um vídeo gravado com um celular pelo jornalista indiano Somreet Bhattacharya sobre um ataque fatal feito por um tigre, no dia 23 de setembro de 2014, no National Zoological Park, de Nova Delhi, Índia, e a reportagem publicada por ele no dia seguinte no The Times of India, maior jornal de língua inglesa daquele país. A hipótese é a de que ambas formas de captação produzem uma apreensão simbólica e relatos diferenciados do fato. O método de análise empregado foi o fenomenológico. O resultado sugere que o vídeo pode ser portador de conteúdos relacionados às imagens arquetípicas e, portanto, ligados à percepção do tempo profundo. Já o relato jornalístico, nesse caso ligado à abordagem das histórias de vida, registraria uma camada mais superficial e imediata do fato.
\end{abstract}

Palavras-chave: narrativas; imagem; fenomenologia; Índia; Brasil.

Abstract: This study reflects on image and journalistic reports through the comparison of a video made by Indian journalist Somreet Bhattacharya using a mobile on a fatal tiger attack occurred on September 23, 2014 at the National Zoological Park in New Delhi, India, and the report published the next day by himself in The Times of India, the largest English-language newspaper in that country. The hypothesis is that both approaching forms produce a differentiated symbolic apprehension and reports of the fact. The method employed was the phenomenological analysis. The result suggests that the video may carry content related to archetypal images, therefore being linked to the perception of a deep time level. The newspaper report, here connected to life stories method, seems to record a more superficial and immediate layer of the fact.

Keywords: narratives; image; phenomenology; India; Brazil.

Resumen: Este estudio propone reflexiones sobre la imagen y relatos periodísticos de comparar el contenido de un vídeo grabado con un celular por el periodista indiano Somreet Bhattacharya durante un ataque mortal por un tigre, el 23 de septiembre de 2014, en el Zoológico Nacional park, en Nueva Delhi, India, y el informe publicado por el al día siguiente en The Times of India, el mayor periódico en idioma Inglés en ese país. La hipótesis es que ambas formas de captación producen una percepción simbólica y diferencian los informes hechos. El método 
empleado fue el análisis fenomenológico. El resultado sugiere que el vídeo puede llevar a contenido relacionado a las imágenes arquetípicas que se vinculan con la percepción del tiempo profundo. Pero el informe periódico, en este caso conectado a la aproximación de las historias de vida, registraría una capa más superficial y inmediata del hecho.

Palabras clave: narrativa; imagen; fenomenología; India; Brasil.

\section{NO PRINCÍPIO, ERA A IMAGEM}

Muito antes da linguagem escrita e, por extensão, dos estudos de jornalismo, as representações imagéticas sobre suportes líticos já constituíam uma forma de expressão e, por extensão, de comunicação humana. "Ainda não é, naturalmente, a linguagem escrita, mas já é a linguagem do escrito, com o sinal ideográfico e o símbolo pictográfico", afirma o filósofo francês Edgard Morin (1988, p. 112).

Essas imagens registradas na aurora da humanidade teriam, na perspectiva da psicologia analítica, se distanciado da esfera biológica (nessa escola de pensamento representada, entre outros, pelo conceito de inconsciente coletivo). "As ideias básicas de todos os motivos seriam representações plásticas de caráter arquetípico, isto é, imagens primordiais, simbólicas, sobre as quais a mente humana se edificou e se diferenciou." (JUNG, 2011, § 15). Segundo o psiquiatra suíço Carl Gustav Jung (1875-1961), a aproximação estritamente intelectual - como pressupõe em geral os estudos do campo jornalístico - a essas representações simbólicas não seriam capazes de abarcá-las em toda sua profundidade. "Não se trata de conceitos científicos, necessariamente isentos de equívocos na interpretação, mas de intuições originárias, extremamente genéricas da mente primitiva, que nunca designam conteúdos específicos." (JUNG, 2011, § 15).

O próprio Jung entende que outros campos científicos, antes dele, haviam deliberado sobre o conceito de arquétipo, que indicaria determinadas formas presentes na psique encontradas em todo o tempo e lugar. "A pesquisa mitológica denomina-as 'motivos' ou 'temas'; na psicologia dos primitivos elas correspondem ao conceito de représentations collectives de Levy-Brühl e no campo das religiões comparadas foram definidas como "categorias de imaginação" por Hubert e Mauss." (JUNG, 2000, § 89). Ainda segundo Jung, "Adolf Bastian designou-as bem antes como 'pensamentos elementares' ou 'primordiais'." (JUNG, 2000, § 89).

Mesmo inovações técnicas feitas milênios depois, como a perspectiva, não romperam essas formas arquetípicas de representações. Antes, foram sobreposições de camadas de novas interpretações sobre os mesmos conteúdos. Como o historiador de arte alemão Aby Waburg 
(1866-1929) define sobre o Renascimento: "até mesmo O nascimento de Vênus, de Boticelli, é uma refiguração de ilustrações medievais, provocada pela arte da Antiguidade redescoberta." (WABURG, 2013, p. 447). Portanto, camadas sobre camadas culturais. Ainda que, nesse caso, a representação já estivesse, nesse momento histórico, esvaziada dos conteúdos religiosos anteriores.

Será o filósofo alemão Walter Benjamim (1892-1940), no século XX, que chamará atenção para a transição da imagem de culto para a midiática, decorrência da perda da unicidade, da autenticidade da obra de arte - ou aura como ele a definia. Com o avanço técnico que possibilitou a reprodutibilidade, a obra deixa de ser expressão de rituais inicialmente mágicos e, posteriormente, religiosos. O 'valor de culto' se transforma em 'valor de exposição' (BENJAMIM, 1994). Dessa forma, muito antes da portabilidade dos smartphones, Benjamim (1892-1940) já destacava a técnica como uma segunda natureza da sociedade contemporânea. Embora, no caso de Benjamim, nunca é demais lembrar o alerta da crítica literária argentina Beatriz Sarlo, de que "as pessoas o citam como se a citação assegurasse (...) a produção de um sentido novo sobre cenários diferentes." (SARLO, 2011, p. 93; AUTOR, 2014).

Neste contexto, o objetivo desse estudo é o de tecer algumas reflexões sobre a relação entre as imagens arquetípicas e a produção jornalística. Seu corpus consiste na imagem captada por um jornalista, por meio de celular, no dia 23 de setembro de 2014, do ataque fatal feito por um tigre a um indiano no National Zoological Park, de Nova Delhi, capital da Índia. Esse vídeo será comparado à reportagem publicada pelo mesmo no dia seguinte no The Times of India, maior jornal de língua inglesa daquele país (embora não o mais prestigiado, a saber o The Hindu). A hipótese é a de que há uma apreensão simbólica e consequentemente um relato diferenciado do fato nessas duas plataformas midiáticas, a imagética e a impressa.

\section{SOBRE ANIMAIS E SERES HUMANOS}

O sociólogo italiano Domênico De Masi recorda que a espécie humana foi muito bem sucedida em transformar seus pontos fracos (como a mandíbula fraca e o longo tempo de permanência da prole junto aos pais) em fortes, caso da transmissão cultural (DE MASI, 2005, p. 50). Não por acaso, a cultura, a organização social e a cosmologia dos povos do paleolítico (cerca de 2.5 milhões de anos) é marcada pelas imagens dos animais como deuses, espíritos tutelares e mestres (CAMPBELL, 1992, p. 232). Essa relação fica evidente nos mitos (LÉVISTRAUSS, 2010). 
Entre 10.000 e 3.000 a.C., a transição para o período neolítico levou à gradual fixação na terra. Os padrões rígidos de um assentamento culminariam, milênios depois, com o êxodo rural e as sociedades urbanas e industriais do século XX, cujo símbolo maior seria a disciplina das linhas fordistas de montagem. Essa transição colocou em cheque a ordem sociocultural prévia, ligada ao nomadismo e à liberdade de ir e vir propiciada pelo seguimento dos rebanhos selvagens.

Ecos desse choque podem ser observados na mitologia dos povos, que reflete essa mediação com as fontes alimentares. As tribos de caçadores, de tradição xamânica, enfatizavam o jejum como forma individual de se alcançar visões. As tribos de agricultores tendem a ter a vida social organizada em torno das cerimônias. Para Campbell, as duas visões podem ser observadas na comparação entre o sacerdote e o xamã. "O sacerdote é o membro socialmente iniciado e solenemente empossado de uma organização religiosa reconhecida, onde detém certa posição e funciona como detentor de um ofício exercido por outros antes dele." (CAMPBELL, 1992, p. 192). Já o xamã "(...) é aquele que, em consequência de uma situação psicológica decisiva pessoal, conquistou certo poder por conta própria. (...)" (CAMPBELL, 1992, p. 193). Para o mitólogo estadunidense, "(...) se voltarmos os olhos para as mitologias dos hindus, persas, gregos, celtas e germanos, reconheceremos imediamente analogias dessa lenda de subjugação dos xamãs." (CAMPBELL, 1992, p. 198). De acordo com ele, os "(...) gigantes foram derrotados, presos embaixo das montanhas, exilados para as regiões tempestuosas nos confins da terra (...)"(CAMPBELL, 1992, p. 198). Usada como analogia, essa dicotomia sobre sacerdotes e xamãs não deixa de ser interessante para refletir sobre a transição enfrentada pelo jornalismo desde o surgimento da internet, que se caracterizou pela ruptura dos sistemas tradicionais de negócios, como a mídia impressa, e pela emergência de novos modelos.

Para o mitólogo alemão Heinrich Zimmer (1890-1943), "A Igreja fez mais do que a cultura romana para privar a mitologia dos celtas, teutões e da primitiva população pré-céltica das Ilhas Britânicas, do velho credo sob o qual viviam, moviam-se e conduziam sua existência" (ZIMMER, 1988, p. 120). Despojada dos seus rituais, sem a forma de culto, a mitologia pagã "se transformou em poesia e saga (...), como sob essa forma nada havia que a Igreja pudesse atacar, continuou a desenvolver-se por toda a Idade Média, oferecendo um rico alimento para a alma" (ZIMMER, 1988, p. 120). Com sua teologia da salvação, a Igreja não tinha nada de comparável para oferecer. O paralelo entre a ênfase da Ciência atual e a eclosão de películas com conteúdos míticos, como os filmes feitos a partir da obra do britânico J. R. R. Tolkien (1892-1973), pode não ser mera coincidência. Por outro lado, o jornalismo ainda busca um 
modelo que reproduza o fenômeno de binge-watching, isto é, de consumo de vários episódios sequenciais de velhas e novas temporadas das séries de televisão via streaming produzidos por provedores globais.

Essa camada civilizatória histórica, é bom lembrar, é recente e fina. Por baixo da pele dos ocidentais ainda há um bárbaro, que aflora em momentos de grandes tensões sociohistóricas - e que pode ser evidenciado na produção e consumos jornalísticos. A Segunda Guerra Mundial pode ser o exemplo mais conhecido, mas o bárbaro emerge hoje, visível como a ponta de um iceberg, em manifestações como a dos grupos xenófobos neonazistas alemães, nos estupros, no vigor com que alguns grupos defendem a pena de morte. Lipovetsky está correto quando identifica o fenômeno do movimento em direção à individualização ou, como ele a chama, de hiperindividualização (LIPOVETSKY; SERROY, 2011). Mas essa camada é frágil e se esfacela quando a consciência individual cede espaço à inconsciência coletiva presente no aglomeramento das grandes massas.

\section{A DIMENSÃO SIMBÓLICA DOS TIGRES INDIANOS}

Antes de analisar o vídeo indiano, refletimos sobre a iconografia dos tigres. Para começar, a representação dos animais é marcada pela ambiguidade. Na mitologia romana, ela pode ser positiva, como a loba que alimenta os fundadores de Roma, Rômulo e Remo, registrada na Eneida por Virgílio no século I a.C (AENEID, 2008). Representações como a dos centauros e das sereias ilustram seres em transição, metade humanos, metade animais. Já mitos como os doze trabalhos de Hércules (na mitologia grega Héracles), filho de Júpiter com uma mortal, sugerem a importância da dominação dessa força animal como um dos passos do herói para ser aceito como um par pelos deuses. "A primeira tarefa consistia em lutar contra o terrível leão que aterrorizava o vale de Nemeia. (...) Após utilizar em vão a clava e as setas contra o leão, Hércules conseguiu estrangular o animal". (BULFINCH, 2013, p. 227).

A palavra tigre tem origem iraniana, chegando ao ocidente por meio do grego tigris e do latim tigre (FERREIRA, 1986, p.1.675). Quer dizer 'flecha', indicando com precisão o ataque rápido, silencioso e feroz desfechado pelo felino asiático (Panthera tigris). Do ponto de vista de comportamento, são territorialistas e solitários: os adultos só se unem para acasalar. O tigre está no topo da pirâmide alimentar, é um predador. Ainda assim, é uma espécie ameaçada: três das oito subespécies estão extintas (SEIDENSTICKER; CHRISTIE; JACKSON, 1999). Além da devastação de seu habitat, colaboram para isso as tradições populares asiáticas, que atribuem 
poderes afrodisíacos à sopa de pênis de tigre, que chega a custar US\$ 350 a tigela (SEIDENSTICKER; CHRISTIE; JACKSON, 1999, p. 219). Ainda assim, dos 29 estados indianos, 17 ainda possuem tigres (COSTA, 2012).

Esse animal evoca ao mesmo tempo uma imagem bela, sensual, majestosa e terrível. Quem registrou esse paradoxo foi William Blake (1757-1827) no poema intitulado The tiger (1993, tradução nossa). Abaixo, a primeira das quatro estrofes:
Tiger! Tiger! burning bright
Tigre, tigre! queimando brilhante In the forests of the night, Nas florestas da noite, What immortal hand or eye Que mão ou olho imortal Could frame thy fearful symmetry?
Poderia enquadrar sua terrível simetria?

Devido à longa ocupação daquele país, a literatura inglesa possui mais exemplos. As relações comerciais com a Índia começaram em 1757, por meio da East India Company. Cem anos mais tarde, em 1858, o país foi anexado ao Império britânico. O British Raj (rāj quer dizer governo em hindi) estendeu-se até 1947, com a declaração da independência. Um filme conhecido é o infantil realizado pelos Estúdios Disney, Mogli, baseado em $O$ livro da selva (1884), de Rudyard Kipling (1865-1936). O escritor anglo-indiano, ganhador do prêmio Nobel de Literatura de 1907, não foi o inventor, mas o divulgador dos cinco Ws e um H, até hoje empregados nos lides jornalísticos. Eles eram memorizados pelo poema abaixo, parte integrante do livro The elephant's child (KIPLING, 1993).

\author{
I keep six honest serving-men \\ (They taught me all I knew); \\ Their names are What and Why and When \\ And How and Where and Who.
}

\author{
Eu mantenho seis honestos serviçais \\ (Eles me ensinaram tudo o que eu sei); \\ Seus nomes são $O$ que, Por que e Quando \\ e Como e Onde e Quem
}

O tigre-de-bengala (Panthera tigris tigris) é o animal símbolo do Bangladesh e da Índia. No plano simbólico, também é a montaria de Durga, "a mãe sagrada, que dá vida e também a devora" (CHEVALIER; GHEERBRANT, 1989, p. 354). Na tradição indiana, os deuses possuem as duas polaridades: Durga é a porção má de Parvati, a doce esposa de Shiva, mãe de Ganesha.

\section{4. ÍNDIA, UMA TERRA DE CONTRASTES}

Para analisar a produção indiana também se faz necessário a tentativa de compreensão do país. A verdade é que nada prepara um ocidental para visitar a Índia. Ou, seria melhor dizer, Índias. Tudo é superlativo no país que possui a sétima maior extensão do mundo (o Brasil é o $5^{\circ}$.). Trata-se da maior democracia do planeta, com 1.267 bilhão de habitantes. O Brasil tem 
aproximadamente um quinto desse total: 202.0 milhões (THE WORLD BANK, 2014). Com PIB (Produto Interno Bruto) de US\$ 1.877 trilhão (2013), a Índia é considerada pelo Banco Mundial com nível de renda média inferior. Já o Brasil, no mesmo ano, apresentou PIB de US\$ 2.246 trilhão, tendo nível de renda considerado renda média superior pela mesma entidade.

Tanto Brasil quanto Índia fazem parte de uma espécie de bloco econômico emergente, os Brics. O termo, originalmente sem o S final, foi concebido pelo economista inglês Jim O'Neill, chefe de pesquisa em economia global do grupo financeiro Goldman Sachs, no estudo de 2001 Building better global economic BRICs. Na época, a sigla designava Brasil, Rússia, Índia e China, mas, desde 2011, a África do Sul ingressou no grupo. Os agora seis grandes consistem em mercados e culturas bastante diversas. No caso de Brasil e Índia, ambos têm metrópoles listadas entre as dez maiores cidades do mundo. Segundo dados da Organização das Nações Unidas, Nova Delhi é a segunda maior cidade do mundo, contando com 25 milhões de habitantes ao se incluir a região metropolitana. Empatadas na quarta posição estão Mumbai e São Paulo, cada uma com 21 milhões de habitantes. (UNITED NATIONS, 2014).

Em termos políticos, Brasil e Índia vivem momentos diferentes. Em 16 de maio de 2014, foi eleito o primeiro ministro Narendra Modi, do Partido Bharatiya Janata (Partido do Povo Indiano, em português), quebrando uma longa continuidade da família Gandhi no poder, desde a independência, em 1947. Pesa sobre Modi (pronuncia-se Modí) uma postura islamofóbica, relativa aos atos de violência não refreados durante sua gestão como ministro-chefe do estado de Gujarat, em 2002. Contudo, desde que assumiu como primeiro ministro, ele tem reforçado a imagem de político dinâmico, voltado ao desenvolvimento interno por meio da redução da burocracia (ele tem maioria no congresso) e externo graças à captação de investimentos. Imagem, aliás, que é vista de forma bastante diferente no contexto da política interna daquele país, que passará por eleições agora em 2018.

O pensamento comunicacional sobre os BRICS está em fase inicial (NORDESTRENG; THUSSU, 2015). Segundo Daya Kishan Thussu, professor em Comunicação Internacional, do Communication and Media Research Institute (CAMRI) da University of Westminster, em Londres, "(...) Bollywood, a maior fábrica de cinema do mundo, (...) não é nem um pouco visível na América Latina, certo? O fato do Brasil ser o maior produtor de telenovelas do mundo também não é lá muito visível." (THUSSU, 2014, p. 143). Para ele, trata-se de "(...) mercados enormes. Imagino que é porque essa interação ainda se encontra em uma fase muito precoce. Entretanto, os BRICS oferecem uma plataforma interessante", diz Thussu (THUSSU, 2014, p. 
143).

\section{CULTURA, REALIDADE E MITOS INDIANOS}

Se tivesse de ser resumida em uma única palavra, uma viagem à Índia poderia ser sintetizada por pobreza. Extrema. Mas uma miséria paradoxalmente high tech, com sadus, hindus santos, seminus falando em celulares, uma paixão nacional. Talvez a melhor explicação para a Índia tenha sido dada por um chef inglês contemporâneo, que lá esteve por meses para escrever um livro sobre curry, o prato típico da culinária local:

Você não pode andar por uma rua lá sem estar consciente de um assalto aos sentidos:
o calor, a poeira, os mendigos, as favelas, a pobreza, a enorme pressão das pessoas
em todos os lugares, e também a profusão de cores, a amizade de todos, a sensação de
que, onde quer que vá, apesar dos problemas terríveis do vasto país, você nunca
realmente se sente ameaçado por ninguém. E, no final, a percepção de que você não
pode mudar nada (...) (STEIN, 2013, p. 8, tradução nossa).

Se os brasileiros têm o jeitinho, os indianos têm o jugaad, termo que designa tentar fazer algo funcionar de uma forma alternativa e criativa, mas também dobrar as regras (COSTA, 2012). O país do líder pacifista Mohandas Gandhi (1869-1948) - que aliás não é uma unanimidade nacional - é uma potência nuclear, possui o terceiro maior exército e é o maior importador de armas do mundo. Quanto à estrutura social, no Brasil a divisão é mais relativa às classes econômicas; na Índia, há o sistema de castas. Brâmanes (religiosos) estão no topo, seguidos de xátrias (guerreiros, governantes), vaixás (comerciantes) e sudras (trabalhadores braçais). Abaixo de todos, intocáveis, os dalits. O casteísmo ainda é ativo, embora proibido pela Constituição desde 1950. Na prática, a distribuição é mais complexa que a exposição didática acima, sendo menos evidente nos grandes centros urbanos. Da mesma forma, é vivo o sistema de casamentos arranjados pela família. Em pleno século XXI, o love marriage, casamento por amor, ainda não é praticado pela maioria dos jovens (COSTA, 2012).

Há, na Índia, um fervor patriótico que não se nota na cultura brasileira. Narrativas épicas milenares como o Mahabárata e o Ramaiana param o país quando são exibidos na televisão. Essa forte aderência, aliás, está no DNA do povo. Estima-se que há 80.000 anos, a India recebeu a primeira migração de seres humanos saídos da África, que atravessaram o Oceano Índico na época com nível mais baixo devido às glaciações - e povoaram o subcontinente indiano. $\mathrm{O}$ professor R. M. Pitchappan, da Madurai Kamaraj University, em Tamil Nadu, identificou o gene dessa primeira leva de africanos (o M130) no sangue do povo Kallar, que habita Madurai e Usilampatti, localizados há $500 \mathrm{~km}$ ao sul de Chennai (WOOD, 2007, p. 15). 
Bem mais tarde, uma segunda leva de migração, esta vinda da Ásia Central, teria sido decisiva para a formação do subcontinente: a dos arianos, ocorrida entre 3.000 e 4.000 anos (WOOD, 2007, p. 17). Os arianos não trouxeram na bagagem apenas os vedas, textos religiosos que implementavam os brâmanes como a casta mais elevada junto aos povos nativos. Eles também trouxeram o sânscrito, língua que em 1786 um juiz e linguista galês, Sir William Jones, identificou como sendo a raiz dos idiomas indo-europeus graças à semelhança com o grego e latim. Um exemplo: pai, father em inglês, pater em grego e latim, e pitar em sânscrito; mãe, mother, é meter em grego e latim e matar em sânscrito. (WOOD, 2007, p. 37).

Apesar da idade milenar dessa civilização, o que fica de uma visita não é a noção histórica, que lá é diáfana e incomensurável, mas a mítica, no sentido circular, cíclico, atemporal. "A história faz sentido nos países europeus onde num passado relativamente recente, bárbaro e não histórico, as coisas começaram a tomar forma", afirma JUNG $(2012, \S 985)$. "Mas na Índia parece não haver nada que não tenha vivido milhares de vezes antes. (...) 'Plus ça change, plus c'est la même chose' (por mais que algo mude, mais permance a mesma coisa) por que haver história nestas circunstâncias?", pergunta Jung, que visitou o país no inverno de 1936-37 (2012, § 986).

Para o indólogo Heinrich Zimmer (1890-1943), "A principal finalidade do pensamento indiano é desvendar e integrar na consciência o que as forças da vida recusaram e ocultaram, não é explorar e descrever o mundo visível" (ZIMMER, 2012, p. 20). Segundo ele, "A filosofia indiana, assim como a ocidental, fala-nos da estrutura e das potências mensuráveis da psique, analisa as faculdades intelectuais dos homens e as operações de sua mente, avalia várias teorias do entendimento humano (...)"(ZIMMER, 2012, p. 21). Além disso, "(...) estabelece os métodos e as leis da lógica, classifica os sentidos e estuda os processos pelos quais apreendemos, assimilamos, interpretamos e compreendemos as experiências." (...)"(ZIMMER, 2012, p. 21).

Segundo Jung, a cultura e a psicologia da Índia lembram seus templos, cujas esculturas representam o universo, inclusive o ser humano, tanto como santo quanto monstro. (JUNG, 2012a, § 1.011). "Talvez seja essa a razão de a Índia se parecer com um sonho: sentimo-nos empurrados de volta para o inconsciente, para aquele mundo não redimido, não civilizado e aborígene com o qual apenas sonhamos enquanto nossa consciência o renega." (JUNG, 2012a, $\S 1.011$ ). Ele completa o raciocínio: "A Índia representa o outro caminho do homem civilizado (...)"(JUNG, 2012a, § 1.011).

\section{IMAGENS DE UMA MORTE ANUNCIADA}


Feita essa fundamentação teórica, procedemos agora à análise fenomenológica (AUTOR, 2014), em uma tentativa de comparar o vídeo de 2'26" de duração do ataque do tigre no zoológico de Nova Delhi em 23 de setembro de 2014, feito por meio de um celular de um jornalista, com a reportagem que ele realizou para o jornal The Times of India no dia posterior. Lembrando que este vídeo se tornou viral, sendo distribuído não só nas redes sociais de todo o mundo, mas também pelos sistemas midiáticos.

Do ponto de vista descritivo, o vídeo (TIGER ATTACK IN DELHI ZOO, 2014) começa exibindo o recinto do tigre. À esquerda, há um homem em posição fetal, agachado dentro de um fosso parcialmente coberto com água. Não se trata de um tigre qualquer, mas de um branco, sinal de virtude real (CHEVALIER; GHEERBRANT, 1989, p. 884). O animal, saberemos depois nascido em cativeiro, começa a bater suavemente com a pata direita no homem, como um gato faria com um rato. O homem inicia vários movimentos de namastê para o tigre, o cumprimento silencioso indiano que sinaliza respeito.

Os observadores começam a gritar com o tigre e ambos, animal e homem, param esse diálogo gestual e olham para cima. Em seguida, retomam os movimentos, com o homem saudando o animal e este devolvendo a saudação com um gesto da pata, como num jogo lúdico e competitivo (HUIZINGA, 1971). A imagem é hipnótica, como se remetesse a um passado longínquo da espécie humana, onde ainda habita o terror de se deparar com um animal selvagem à espreita. Como espécie, guardamos o conhecimento ancestral de que sempre fomos mais fracos que os predadores (DE MASI, 2005, p. 50). Esse saber se revela, ali, na posição do corpo, que tenta se proteger na posição encolhida como nossos antepassados quando ainda não havia linguagem. Há nova hesitação por parte do tigre, atraído pelos chamados sonoros à direita, possivelmente de um tratador.

Quando o animal volta a atenção para o homem, o momento lúdico se perdeu: o animal parece ter reencontrado o instinto de sua espécie. O jogo agora é mortal. Como sugere o filósofo tcheco-brasileiro Vilém Flusser, "(...) a morte é o tema exclusivo e universal da vida." (FLUSSER, 2002, p.97). Ou como diz o psiquiatra alemão Sigmund Freud (1856-1939), estamos diante de uma dança de Eros, enquanto uma pulsão amorosa pela vida, e Tanathos, enquanto uma pulsão de repouso e morte, no sentido de um desejo profundo de não separação, de retorno à situação uterina, fetal (FREUD, 2010, p. 85-86).

O embate entre Eros e Tanathos encontra-se em outras situações, como na relação sexual. Não por acaso, os franceses chamam o período imediatamente após o orgasmo de la petite mort, a pequena morte. $\mathrm{O}$ ato sexual é provavelmente o maior momento de entrega ao 
outro, onde o eu se torna tu, como diz o filósofo austríaco Martin Buber (1878-1965). "O facea-face aparece e se desvanece, os eventos de relação se condensam e se dissimulam e é nesta alternância que a consciência do parceiro, que permanece o mesmo, que a consciência do EU se esclarece e aumenta cada vez mais." (BUBER, 1971, p. 32).

No plano midiático, o vídeo ressalta a noção de que praticamente toda notícia tem em si um vínculo com a morte, seja ela uma catástrofe, crise político-econômica ou o início do relacionamento de celebridades. Desse modo, "a consciência da morte significa, portanto, simultaneamente, tanto medo e rejeição como atração e curiosidade" (BAITELLO JUNIOR, 1999, p.109). O ser é humano porque sabe que no fim morrerá. E a vida só é possível porque fazemos de conta que somos imortais (FLUSSER, 2002).

Quando a cena volta ao recinto do zoológico, o tigre redescobriu-se predador e o homem voltou a ser sua frágil e ancestral presa. $\mathrm{O}$ animal joga-se sobre ele, mira a veia jugular e, com isso, o homem tem o pescoço quebrado. O corpo magro é arrastado para o fundo do recinto, onde desaparece na vegetação. Uma última imagem, interrompida, talvez pelo horror, revela o tigre sobre o cadáver, fazendo um movimento que sugere a devoração.

A imagem tem uma força notável, como a reencenação de um antigo ritual de sacrifício humano, com seu mysterium tremendum et fascinans (Otto apud Cassirer, 1994). Sua característica principal, talvez, seja a de ser maior do que a vida biológica, deixando o plano do profano para colocar-se na dimensão do sagrado.

\section{O DIA SEGUINTE: CONSIDERAÇÕES DO RELATO JORNALÍSTICO}

A reportagem em inglês publicada no dia 25 de setembro de 2014 no jornal The Times of India é assinada pelo repórter Somreet Bhattacharya. Ainda que não esteja em estilo de jornalismo literário, está muito bem escrita. Como no poema de Kipling, ela responde aos cinco Ws (o que, por que, quando, como e onde) e se aventura a lançar hipóteses sobre o H (como). Ficamos sabendo que Maqsood, 20, a vítima, morava com a família num barraco sob um viaduto no centro de Delhi, região empobrecida da cidade. Uma visita ao zoo, três meses antes do acidente fatal, em junho de 2014, o deixara apaixonado por tigres. O avô dele, Mohammad Tahir, disse que o neto nunca havia dito o motivo da paixão.

Maqsood descarregava sacos de caminhões para ganhar entre Rs 100-150 rúpias por mês, menos de dez reais. Desempregado há quatro meses, dizia ir procurar trabalho, mas escapava para o zoológico às tardes, gastando o pouco dinheiro que tinha com a entrada. Adil, um amigo, disse que Maqsood havia abandonado a escola na oitava série para trabalhar. A 
notícia da morte reaproximou a mãe do rapaz, Ishrat, empregada doméstica, ao pai, Mehfuz, condutor de riquixá. O irmão mais novo, Mehmood, trabalha na cidade de Jaipur.

Maqsood era casado há um ano com Fátima, que estava grávida de sete meses. Após a fatalidade, ela havia partido para sua cidade natal, Kolkata, por não aguentar ver os vídeos da morte do marido sendo exibidos repetidamente na televisão. Maqsood era considerado distraído pelos ex-patrões. Seu último empregador, Lalit, dono de uma fábrica de papelão em Anand Parbat, disse que Maqsood costumava fazer o trabalho dos outros e deixar o próprio para trás. Um amigo, Satish, disse que Maqsood usava o celular sem chip para ouvir músicas, tirar fotografias e armazenar imagens, algumas delas de tigres.

Por meio do relato jornalístico, descemos do plano do sagrado, do mito e do transcendente das imagens para o do profano. No contexto do escalonamento de tempo do historiador francês Fernand Braudel (1902-1982), o relato não atingiu os níveis de média duração, socioeconômico e conjuntural, nem o de longa duração, geológico. Ou profundo, como sugere Siegfreid Zielinsky, professor de Teoria da Mídia da Universidade Técnica de Berlim (ZIELINSKY, 2006). Limitou-se à narrativa de fôlego curto, ainda que bem redigida e dramática. Restringiu-se ao "(...) tempo curto, à medida dos indivíduos, da vida cotidiana, de nossas ilusões, de nossas rápidas tomadas de consciência - o tempo, por excelência, do cronista, do jornalista." (BRAUDEL, 1992, p. 45).

Malena Contreras diz que ocorre um achatamento da dimensão simbólica da linguagem no jornalismo contemporâneo (CONTRERA, 2004, p. 41). De fato, após ler a reportagem, ficamos sem saber quais os nexos e sentidos mais profundos da triste história de Maqsood. Que não teve a sorte do protagonista de As Aventuras de Pi, que, como Hércules, sofreu, mas venceu o animal. Já Maqsood, depois de ter sido marginalizado pela sociedade e vitimado por um tigre, ainda foi simbolicamente devorado pela mídia. A imagem crua do fato, com suas múltiplas camadas de complexidade, venceu os limites do verbo.

Um exercício interessante seria o de uma produção multimídia que mesclasse esses dois tempos, o profundo, denso, mítico da imagem do vídeo, arquetípica, com o tempo da narrativa jornalística, limitado pelo tempo, espaço e focado no humano. Nos estudos em jornalismo, os trabalhos que talvez mais se detenham nessa questão sejam os ligados ao Jornalismo Literário (AUTOR, 2016). Como a International Association for Literary Journalism Studies (IALJS) preconiza, trata-se de estudos de jornalismo como literatura e não sobre literatura, como é mais comum de vermos no Brasil. No plano da estética, o que teríamos em geral de proposta para um texto mais denso ainda ficaria na esfera dos quatro recursos propostos no estudo clássico 
do jornalista estadunisense Tom Wolfe (2005), em especial a questão do símbolo de status de vida. Estudos mais recentes do campo sugerem que só isso não basta para retratar a complexidade da vida atual. Seria necessário, por exemplo, abarcar também os níveis sociológico e psicológico, por exemplo. Ainda assim, o resultado do presente estudo parece sugerir que nem mesmo a adição dessas camadas poderiam ser suficientes para garantir uma profundidade semelhante à da que as imagens podem propociar. Num mundo de convergência midiática, a sinergia pode ser um dos caminhos possíveis para se propor às produções jornalísticas a experiência imersiva desencadeada pelo fenômeno do binge-watching. No qual tamanho, tempo e custo parecem ser questões menores frente à adesão feita pelo(a) usuário(a) em relação a produtos que opta por consumir devido a fatores muito mais relacionados ao universo dos fãs e a gameficação - com suas formas de recompensa além do conteúdo em si do que aos de um(a) leitor(a) tradicional.

\section{REFERENCIAS}

AS AVENTURAS de Pi. Direção de Ang Lee. Produção de Ang Lee; Gil Netter; David Womark. Intérpretes: Suraj Sharma; Irrfan Khan; Adil Hussain; Tabu; Gerard Depardieu. Roteiro: David Magee. Música: Mychael Danna. Estados Unidos: 20th Century Fox; Rhythm And Hues, 2012. (127 min.), son., color. Legendado. Baseado no romance de Yann Martel.

BAITELLO JÚNIOR, Norval. O animal que parou os relógios: ensaios sobre comunicação, cultura e mídia. 2a. edição. São Paulo: Annablume, 1999.

BENJAMIM, Walter. A obra de arte na era de sua reprodutibilidade técnica. In: BENJAMIM, Walter. Magia e técnica, arte e política: ensaios sobre literatura e história da cultura. 7. ed. São Paulo: Brasiliense, 1994. p. 165-196. (Obras Escolhidas). V. 1.

BHATTACHARYA, Somreet. Maqsood's obsession with tigers led to his death. 25 set. 2014. The Times of India. Disponível em: <http://timesofindia.indiatimes.com/city/delhi/Maqsoods-obsessionwith-tigers-led-to-his-death/articleshow/43358473.cms>. Acesso em: 21 jan. 2015.

BLAKE, William. The tiger. London: Harcourt Brace \& Company, 1993.

BRAUDEL, Fernand. Escritos sobre a História. São Paulo: Perspectiva, 1992.

BUBER, Martin. Eu e Tu. São Paulo: Centauro, 2001.

BULFINCH, Thomas. O livro da mitologia: a idade da fábula. São Paulo: Martins Claret, 2013.

CAMPBELL, Joseph. As máscaras de Deus: mitologia primitiva. São Paulo: Palas Athena, 1992.

CASSIRER, Ernst. Ensaio sobre o Homem: Introdução a uma filosofia da cultura humana. São Paulo: Martins Fontes, 1994. 
CHEVALIER, Jean; GHEERBRANT, Alain. Dicionário de símbolos: mitos, sonhos, costumes, gestos, formas, figuras, cores, números. 2. ed. Rio de Janeiro: José Olympio, 1989.

CONTRERA, Malena Segura. Jornalismo e mídia: paranoia e crise das competências simbólicas. In: CONTRERA, Malena; GUIMARÃES, Luciano; PELEGRINI, Milton; SILVA, Maurício Ribeiro. O espírito do nosso tempo: ensaios de semiótica da cultura e da mídia. São Paulo: Annablume/Cisc, 2004.

COSTA, Florência. Os indianos. São Paulo: Contexto, 2012.

DE MASI, Domenico. Descoberta e invenção: Criatividade e grupos criativos. Rio de Janeiro: Sextante, 2005 (V. 1.).

FERREIRA, A. B. H. Novo Dicionário da Língua Portuguesa. 2a. ed. Rio de Janeiro: Nova Fronteira, 1986.

FLUSSER, Vilém. Da religiosidade: a literatura e o senso de realidade. São Paulo: Escrituras, 2002. FREUD, Sigmund. O mal-estar na civilização: novas conferências introdutórias à psicanálise e outros textos (1930-1936). São Paulo: Companhia das Letras, 2010.

HUIZINGA, Johan. Homo ludens: o jogo como elemento da cultura. São Paulo: Editora da Universidade de S. Paulo/Perspectiva, 1971.

JUNG, Carl Gustav. A Índia: um mundo de sonhos. In: JUNG, Carl Gustav. Civilização em transição. 5. ed. Petrópolis/RJ: Vozes, 2012. Cap. 23. p. 236-245

A prática da psicoterapia. 14. ed. Petrópolis/RJ: Vozes, 2011. (V. 16/2). Obra completa.

O que a Índia nos pode ensinar. In: JUNG, Carl Gustav. Civilização em transição. 5. ed. Petrópolis/RJ: Vozes, 2012a. Cap. 24. p. 246-251.

Os arquétipos e o inconsciente coletivo. Petrópolis/RJ: Vozes, 2000. (V. IX/1). Obra completa.

KIPLING, Rudyard. The elephant's child: and other just so stories. New York: Dover Publications, 1993.

LÉVI-STRAUSS, Claude. O cru e o cozido. São Paulo: Cosac Naify, 2010.

LIMA JÚNIOR, Walter Teixeira. Mídias conectadas e jornalismo participativo. In: MARQUES, Angela et all. Esferas públicas, redes e jornalismo. Rio de Janeiro: E-papers, 2009, p. 168-188.

LIPOVETSKY, Gilles; SERROY, Jean. A cultura-mundo: resposta a uma sociedade desorientada. São Paulo: Companhia das Letras, 2011.

AUTOR. Jornalismo Literário: tradição e inovação. Florianópolis: Insular, 2016.

MORIN, Edgard. O enigma do homem. São Paulo: Círculo do Livro, 1988. 
NORDESTRENG, Kaarle; THUSSU, Daya Kishan. Mapping BRICS media. London/ New York: Routledge, 2015.

PESSIS, Anne-marie. Imagens da pré-história: Parque Nacional Serra da Capivara. São Paulo: Fundham/petrobrás, 2003.

SARLO, Beatriz. Sete ensaios sobre Walter Benjamim e um lampejo. Rio de Janeiro: UFRJ, 2011.

SEIDENSTICKER, John; CHRISTIE, Sara; JACKSON, Peter. Riding the tiger: tiger conservation in human-dominated landscapes. Cambridge: Cambridge University Press, 1999.

STEIN, Rick. India. London: BBC Books, 2013.

TUSSU, Daya Kishan. The West, the "rest" and the internationalization of Media Studies: "Chindia", BRICS and soft power. Matrizes. São Paulo, v. 8, n 1, p. 137-149, jan./jun. 2014. Disponível em: < http://www.matrizes.usp.br/index.php/matrizes/article/view/597/pdf>. Acesso em: 21 jan. 2015. Entrevista concedida à Andrea Medrado.

THE WORLD BANK. 2014. Disponível em: < http://data.worldbank.org>. Acesso em: 20 jan. 2015.

UNITED NATIONS. World's population increasingly urban with more than half living in urban areas. 10 jul. 2014. Disponível em: <http://www.un.org/en/development/desa/news/population/worldurbanization-prospects-2014.html>. Acesso em: 21 jan. 2015.

TIGER ATTACK IN DELHI ZOO. Nova Delhi, 24 set. 2014. 2`16", sonoro, sem legendas. Disponível em: <http://www.dailymotion.com/video/x2610kv_actual-video-of-tiger-attack-in-delhizoo_animals>. Acesso em: 21 jan. 2015.

VIRGIL. Aeneid. Salt Lake City: The Gutemberg Project, 2008. 1697 John Dryden translation. Disponível em: 〈http://www.gutenberg.org/files/228/228-h/228-h.htm〉. Acesso em: 20 jan. 2015.

WABURG, Aby. A renovação da antiguidade pagã: contribuições científico-culturais para a história do Renascimento europeu. Rio de Janeiro: Contraponto, 2013.

WOLFE, T. Radical chique e o novo jornalismo. São Paulo: Companhia das Letras, 2005.

WOODS, Michael. India. London: Basic books, 2007.

ZIELINSKI, Siegfried. Arqueologia da mídia: em busca do tempo remoto das técnicas do ver e do ouvir. São Paulo: Annablume, 2006.

ZIMMER, Henrich. A conquista psicológica do mal. São Paulo: Palas Athena, 1988.

Filosofias da Índia. 5. ed. São Paulo: Palas Athena, 2012.

Original recebido em: 16 de outubro de 2015

Aceito para publicação em: 22 de agosto de 2017

Monica Martinez 
PROGRAMA DE PÓS-GRADUAÇÃO EM COMUNICAÇÃO DA UNIVERSIDADE FEDERAL DE SANTA MARIA

Doutora em Ciências da Comunicação pela ECA-USP, tem pós-doutorado pela Umesp e estágio pós-doutoral pela Universidade do Texas em Austin. É docente do Programa de Pós-

Graduação em Comunicação e Cultura da Uniso (Sorocaba - SP).

\section{(@) $(\mathcal{O Q}$}

Esta obra está licenciado com uma Licença

Creative Commons Atribuição-NãoComercial-CompartilhaIgual 4.0 Internacional 